\title{
Genetic Diversity and Symbiotic Efficiency of Indigenous Common Bean Rhizobia in Croatia
}

\author{
Ines Pohajda ${ }^{1}$, Katarina Huić Babić ${ }^{2}$, Ivana Rajnović, Sanja Kajić ${ }^{3}$ and Sanja Sikora ${ }^{3 *}$ \\ ${ }^{1}$ Advisory Service, Savska cesta 41, HR-10000 Zagreb, Croatia \\ ${ }^{2}$ Genera, Svetonedeljska 2, Kalinovica, HR-10436 Rakov Potok, Croatia \\ ${ }^{3}$ University of Zagreb, Faculty of Agriculture, Department of Microbiology, Svetošimunska 25, \\ HR-10000 Zagreb, Croatia \\ Received: April 13, 2016 \\ Accepted: July 29, 2016
}

\begin{abstract}
Summary
Nodule bacteria (rhizobia) in symbiotic associations with legumes enable considerable entries of biologically fixed nitrogen into soil. Efforts are therefore made to intensify the natural process of symbiotic nitrogen fixation by legume inoculation. Studies of field populations of rhizobia open up the possibility to preserve and probably exploit some indigenous strains with hidden symbiotic or ecological potentials. The main aim of the present study is to determine genetic diversity of common bean rhizobia isolated from different field sites in central Croatia and to evaluate their symbiotic efficiency and compatibility with host plants. The isolation procedure revealed that most soil samples contained no indigenous common bean rhizobia. The results indicate that the cropping history had a significant impact on the presence of indigenous strains. Although all isolates were found to belong to species Rhizobium leguminosarum, significant genetic diversity at the strain level was determined. Application of both random amplification of polymorphic DNA (RAPD) and enterobacterial repetitive intergenic consensus-polymerase chain reaction (ERIC-PCR) methods resulted in similar grouping of strains. Symbiotic efficiency of indigenous rhizobia as well as their compatibility with two commonly grown bean varieties were tested in field experiments. Application of indigenous rhizobial strains as inoculants resulted in significantly different values of nodulation, seed yield as well as plant nitrogen and seed protein contents. The most abundant nodulation and the highest plant nitrogen and protein contents were determined in plants inoculated with $R$. leguminosarum strains $S_{17 / 2}$ and $\mathrm{S}_{21 / 6}$. Although, in general, the inoculation had a positive impact on seed yield, differences depending on the applied strain were not determined. The overall results show the high degree of symbiotic efficiency of the specific indigenous strain $S_{21 / 6}$. These results indicate different symbiotic potential of indigenous strains and confirmed the importance of rhizobial strain selection. These are the first studies of indigenous common bean rhizobia in Croatia that provide the basis for further characterization and selection of highly efficient indigenous strains and their potential use in agricultural practice and future research.
\end{abstract}

Key words: nitrogen fixation, Rhizobium leguminosarum, common bean, indigenous strains, RAPD, ERIC-PCR, symbiotic efficiency

\section{Introduction}

Natural process of symbiotic nitrogen fixation has a unique role in a sustainable legume production. Nodule bacteria, collectively named rhizobia, in symbiotic associations with legumes enable considerable entries of biologically fixed nitrogen into ecosystems. In order to maxi- 
mize the use of symbiotic nitrogen fixation, inoculation of legume seed with efficient rhizobial strains has become usual procedure in agriculture. The application of rhizobial inoculants enables considerable reduction of mineral nitrogen fertilization, which is of great ecological and economic importance. Nitrogen fixing capacity in agricultural systems depends on rhizobial strain, host plant and environmental conditions (1). It is well known that rhizobial strains strongly differ in their properties like symbiotic efficiency, competitiveness with other rhizobia in the soil, compatibility with host plant, and adaptive ability to stress conditions in the soil. Therefore, the selection of high quality rhizobial strains is one of the main presumptions for successful inoculation. Furthermore, in order to maximize the contribution of biologically fixed nitrogen in common bean production, it is also very important to select the most effective symbiotic associations between the common bean cultivar and the rhizobial strain. However, indigenous rhizobial strains can be present in some soils. In specific environmental conditions, these strains usually show higher competitiveness and adaptive ability than commercial strains, while their symbiotic efficiency is usually unknown. Therefore, in order to improve the beneficial effect of common bean inoculation, it is important to determine the actual composition and the characteristics of rhizobial field population.

Compared to other legumes, common bean can form symbiotic relations with a number of species mostly belonging to the genus Rhizobium (2-4). Despite the great symbiotic potential of common bean, in comparison with other legumes, it fixes considerably small amounts of atmospheric nitrogen (5). It has been recognized that symbiosis of common bean with a number of rhizobial species has a negative correlation with the degree of nodulation and nitrogen fixing capacity (6).

Common bean (Phaseolus vulgaris L.) is the most important grain legume in human diet due to the high content of valuable nutrients that have beneficial effects on human health. Common beans are important source of proteins, complex carbohydrates, dietary fibre, vitamins and minerals and have very low content of saturated fat and cholesterol (7). Although the common bean originates from the Americas, it is widely distributed in various parts of the world. In Croatia, common bean is a traditional but completely marginalized crop despite very favourable conditions for its cultivation. In order to improve and expand the production of beans in Croatia, different investigations have been carried out, mainly with the most widespread cultivars sown in Croatia called Trešnjevac and Slavonski zeleni, while the studying of common bean rhizobia has been neglected (8).

However, many authors from different countries that are the main common bean producers have studied the distribution and composition of indigenous common bean rhizobia as well as their symbiotic efficiency (9-11).

For the first time, this study has provided insight into the composition and diversity of indigenous rhizobial populations that nodulate common bean in different soil types in Croatia. Besides, symbiotic characterization of indigenous strains is a prerequisite for selection of the most efficient strains that are at the same time well-adapted to the soils of central Croatia. Investigations conducted so far in Croatia involved indigenous rhizobial populations that nodulate soybean $(12,13)$, field pea $(14)$ and alfalfa (15). It is assumed that indigenous rhizobial strains with different symbiotic characteristics are present in the soils of central Croatia. The main aim of the present study is to identify and characterize the indigenous common bean rhizobia isolated from different field sites in central Croatia, to determine genetic diversity within rhizobial field population and to evaluate symbiotic properties of indigenous strains.

This study is the beginning of research of indigenous populations of common bean rhizobia in Croatia. The results will provide the first data on the composition and characteristics of indigenous populations in central Croatia.

\section{Materials and Methods}

Twenty-three soil samples were collected for isolation of indigenous common bean rhizobia from different sites in Zagreb County in central Croatia. Soil chemical analyses included determination of soil acidity in water and in $1 \mathrm{M} \mathrm{KCl}$, humus content by Tjurin's method (16), total nitrogen content by the modified Kjeldahl method (17), and available phosphorus and potassium by the method described by Egner et al. (18).

In greenhouse pot experiment, surface-sterilized common bean seeds were sown directly into soil samples collected from different field sites. Each experimental pot contained about $3 \mathrm{~kg}$ of soil sample. Rhizobial strains were isolated from surface-sterilized nodules following a standard protocol (19).

Genomic DNA from all strains was extracted by using a NucleoSpin ${ }^{\circledR}$ tissue kit (Macherey-Nagel, Duren, Germany) in accordance with the manufacturer's protocols. Isolates were identified at the species level by $16 \mathrm{~S}$ rDNA genotyping using polymerase chain reaction-restriction fragment length polymorphism (PCR-RFLP), while random amplification of polymorphic DNA (RAPD) and enterobacterial repetitive intergenic consensus-polymerase chain reaction (ERIC-PCR) were used for strain differentiation as previously described (20). Identification at species level (16S rDNA PCR-RFLP) included rhizobial strains as follows: Rhizobium tropici 11418, R. phaseoli 30137, R. etli 11541, R. leguminosarum 6039 (Deutsche Sammlung von Mikroorganismen und Zellkulturen (DSMZ), Braunschweig, Germany) and the reference strain R. leguminosarum 3622 (Institute of Grassland and Environmental Research, Aberystwyth, UK).

Field trials were set up to investigate the symbiotic properties of common bean rhizobia under the agroecological conditions of central Croatia. The two-year field trials (2008 and 2009) were conducted at two sites (Velika Gorica and Maksimir, Zagreb) positioned $26 \mathrm{~km}$ apart. Two-factorial field trials were laid out according to the randomized block design with four replications. Trial factors included: (i) rhizobial strains ( $R$. leguminosarum isolates: $S_{7 / 3}, S_{8 / 1}, S_{12 / 5}, S_{17 / 2}$ and $S_{21 / 6}$, reference strain $R$. leguminosarum 3622 and uninoculated control $S_{\mathrm{B} 0}$ ), and (ii) common bean cultivars (Trešnjevac and Slavonski zeleni). The size of the experimental plot was $12 \mathrm{~m}^{2}$ with six rows, 
leaving $0.50 \mathrm{~m}$ between them. The indigenous $R$. leguminosarum strains and reference strain $R$. leguminosarum 3622 were used for inoculant preparation. Strains were grown on yeast mannitol broth (YMB) (19) at $28^{\circ} \mathrm{C}$. Cultures were harvested at the late exponential phase of growth and used for preparation of peat-based inoculants. Inoculants were applied to common bean seeds to obtain approx. $10^{6}$ cells per seed. The following parameters were recorded to evaluate the symbiotic efficiency of indigenous and reference strains: nodule number and nodule dry mass $(\mathrm{g})$, total nitrogen content $(\%)$ in the above-ground part of plants (21), seed protein content (\%) and seed yield (t/ha). All data obtained were processed by analysis of variance (ANOVA) using MSTAT-C statistical program (Michigan State University, East Lansing, MI, USA).

\section{Results and Discussion}

The results of greenhouse pot experiment revealed that indigenous common bean rhizobia were not widespread in the studied part of central Croatia. Out of 23 collected soil samples, indigenous rhizobial populations were present only in five. In total, eighteen rhizobial strains were isolated from all soil samples. Soil samples containing common bean rhizobia were collected from different field sites. Previous cultivation of different crops had a significant impact on the occurrence of indigenous strains. Bean was previously grown at three out of five field sites at which the presence of common bean rhizobia was recorded (Table 1). Andrade et al. (22) also deter-

Table 1. Origin and designation of Rhizobium leguminosarum isolates used in the study

\begin{tabular}{|c|c|c|c|}
\hline $\begin{array}{l}\text { Sampling } \\
\text { site }\end{array}$ & Coordinates & $\begin{array}{l}\text { Previous crop } \\
\text { on the site }\end{array}$ & $\begin{array}{l}\text { Strain } \\
\text { designation }\end{array}$ \\
\hline Staro Čiče & $\begin{array}{l}45^{\circ} 41^{\prime} 26.9^{\prime \prime} \mathrm{N} \\
16^{\circ} 06^{\prime} 24.9^{\prime \prime} \mathrm{E}\end{array}$ & orchard & $\begin{array}{l}\mathrm{S}_{7 / 1}, \mathrm{~S}_{7 / 2}, \mathrm{~S}_{7 / 3}, \\
\mathrm{~S}_{7 / / 5}, \mathrm{~S}_{7 / 6}\end{array}$ \\
\hline Belovar & $\begin{array}{l}45^{\circ} 53^{\prime} 05.9^{\prime \prime} \mathrm{N} \\
16^{\circ} 10^{\prime} 22.3^{\prime \prime} \mathrm{E}\end{array}$ & zucchini & $S_{8 / 1} S_{8 / 2}$ \\
\hline $\begin{array}{l}\text { Sv. Ivan } \\
\text { Zelina }\end{array}$ & $\begin{array}{l}45^{\circ} 58^{\prime} 13.0^{\prime \prime} \mathrm{N} \\
16^{\circ} 14^{\prime} 51.0^{\prime \prime} \mathrm{E}\end{array}$ & $\begin{array}{l}\text { common } \\
\text { bean }\end{array}$ & $\begin{array}{l}\mathrm{S}_{12 / 5}, \mathrm{~S}_{12 / 6,} \mathrm{~S}_{12 / 7}, \\
\mathrm{~S}_{12 / 9}\end{array}$ \\
\hline Pleso & $\begin{array}{l}45^{\circ} 43^{\prime} 25.0^{\prime \prime} \mathrm{N} \\
16^{\circ} 04^{\prime} 51.9^{\prime \prime} \mathrm{E}\end{array}$ & $\begin{array}{l}\text { common } \\
\text { bean }\end{array}$ & $\begin{array}{l}S_{17 / 1}, S_{17 / 2}, S_{17 / 3}, \\
S_{17 / 4}\end{array}$ \\
\hline Bapča & $\begin{array}{l}45^{\circ} 44^{\prime} 34.8^{\prime \prime} \mathrm{N} \\
16^{\circ} 06^{\prime} 15.3^{\prime \prime} \mathrm{E}\end{array}$ & $\begin{array}{l}\text { common } \\
\text { bean }\end{array}$ & $S_{21 / 1}, S_{21 / 4}, S_{21 / 6}$ \\
\hline
\end{tabular}

mined higher Phaseolus-nodulating rhizobial populations in soils where common bean had previously been grown. Indigenous rhizobial strains were isolated from soil samples that were characterized by neutral or almost neutral $\mathrm{pH}$ values. Besides, all soil samples were well supplied with nitrogen, while available phosphorus, potassium and humus content varied significantly (Table 2). Chemical characteristics were determined in all collected soil samples (data not shown). Most soil samples without indigenous rhizobia were also characterized by neutral $\mathrm{pH}$ values, while only three soil samples had low $\mathrm{pH}$ values. Therefore, our results indicate that soil acidity could not be the most relevant factor in indigenous strain distribution.

Genetic diversity of indigenous rhizobial populations was studied by using different PCR fingerprinting methods such as 16S rDNA PCR-RFLP, ERIC-PCR and RAPD. The 16S rRNA gene fulfils all of the requirements for a good phylogenetic marker, such as functional conservation, ubiquitous distribution, conserved size and information content, and the presence of evolutionary conserved regions alongside highly variable structural elements (23).

Eighteen rhizobial strains isolated from common bean nodules were compared with reference and/or type strains representing Rhizobium leguminosarum, Rhizobium etli, Rhizobium tropici and Rhizobium phaseoli. Dendrogram derived from PCR-RFLP of 165 rDNA revealed that all common bean isolates differ significantly from $R$. tropici, $R$. etli and R. phaseoli type strains, while they were identical to $R$. leguminosarum type strain (data not shown). These results suggest that all common bean isolates can be regarded as $R$. leguminosarum. Low genetic diversity of bean-nodulating rhizobia was also determined in the central region of Chile where R. etli was found to be the dominant species (24). On the contrary, considerably higher diversity within common bean rhizobial populations was determined in other countries, such as Ethiopia, China and Nepal (25-27).

Further characterization was performed by RAPD and ERIC-PCR, which enable intraspecies differentiation. ERIC sequences are widespread in the genome of Gram-negative soil bacteria. This technique is considered a powerful tool for strain differentiation in bacterial taxonomy (28). RAPD fingerprinting method was also successfully used for assessing genetic diversity of rhizobia (29-31).

Characteristic RAPD profiles were obtained for each particular rhizobial strain. Dendrogram derived from

Table 2. Chemical properties of soil samples used in the study

\begin{tabular}{|c|c|c|c|c|c|c|c|}
\hline & \multicolumn{5}{|c|}{ Strain isolation site } & \multicolumn{2}{|c|}{ Field experiment } \\
\hline & $\begin{array}{l}\text { Staro } \\
\text { Čiče }\end{array}$ & Belovar & $\begin{array}{c}\text { Sv. Ivan } \\
\text { Zelina }\end{array}$ & Pleso & Bapča & $\begin{array}{l}\text { Velika } \\
\text { Gorica }\end{array}$ & $\begin{array}{c}\text { Maksimir, } \\
\text { Zagreb }\end{array}$ \\
\hline $\mathrm{pH}$ (in water) & 7.02 & 7.04 & 7.61 & 7.44 & 7.46 & 5.24 & 7.28 \\
\hline pH (in $1 \mathrm{M} \mathrm{KCl)}$ & 6.41 & 6.55 & 7.25 & 6.89 & 7.17 & 4.35 & 6.67 \\
\hline$w$ (humus) $/ \%$ & 2.70 & 4.80 & 3.00 & 5.50 & 4.80 & 4.30 & 1.30 \\
\hline$w($ total nitrogen $) / \%$ & 0.15 & 0.24 & 0.14 & 0.31 & 0.26 & 0.23 & 0.07 \\
\hline$w\left(\mathrm{P}_{2} \mathrm{O}_{5}\right) /(\mathrm{mg} / 100 \mathrm{~g})$ & 3.20 & 35.60 & 10.70 & 3.20 & 42.00 & 1.00 & 31.90 \\
\hline$w\left(\mathrm{~K}_{2} \mathrm{O}\right) /(\mathrm{mg} / 100 \mathrm{~g})$ & 13.00 & 10.20 & 14.50 & 15.80 & 30.00 & 10.20 & 11.40 \\
\hline
\end{tabular}


RAPD fingerprints revealed that one isolate $\left(S_{21 / 6}\right)$ differed significantly from all the other strains, which were divided into two main clusters (Fig. 1).

Similar results were obtained by the ERIC-PCR method. All isolates were divided into two main clusters, with strains $S_{12 / 5}, S_{21 / 4}$ and $S_{21 / 6}$ being significantly different from all other common bean rhizobia studied (Fig. 2). Comparison of the data obtained by RAPD and ERIC-PCR fingerprinting allows the conclusion that the application of both methods showed similar grouping of strains. The obtained results revealed that indigenous rhizobial strains were mostly grouped according to the site of their origin. The only exception was determined for the indigenous strains isolated from the location Sv. Ivan Zelina $\left(S_{12}\right)$ and particularly for the isolates from the location Bapča $\left(S_{21}\right)$, which were not grouped within the same cluster. However, besides isolates obtained from these two locations, both dendrograms indicate considerable influence of biogeographic factors on genetic diversity within indigenous rhizobial population. The results of some other studies also suggest biogeographic structuring of rhizobial populations (32-34).

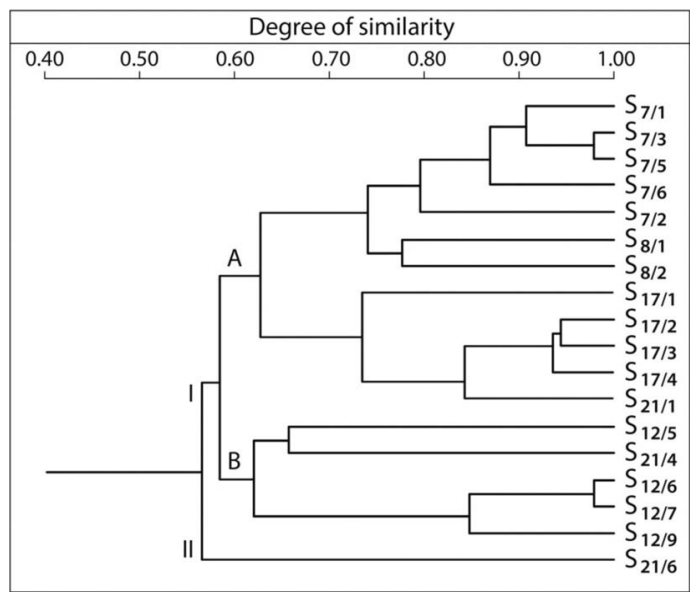

Fig. 1. Dendrogram of common bean rhizobia isolated in this study derived from random amplification of polymorphic DNA (RAPD) patterns

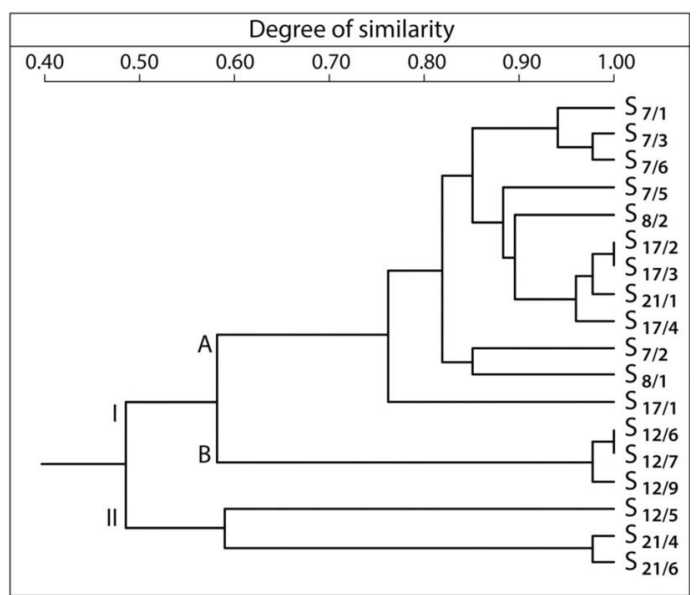

Fig. 2. Dendrogram of common bean rhizobia isolated in this study derived from enterobacterial repetitive intergenic consensus (ERIC) patterns
Two-year field trials were carried out to evaluate the symbiotic properties of indigenous rhizobial strains under the agroecological conditions of central Croatia. The sparse nodulation was determined in uninoculated plants, indicating the presence of some indigenous common bean rhizobia as was also noted in previous reports (35). Rhizobia belong to the group of soil bacteria, and therefore their presence in natural environment is quite common. However, since only sporadic nodulation was noticed at control plots, it is difficult to assume that it will have a significant impact on inoculation response. The results showed that the most abundant nodulation was achieved by inoculation with indigenous strains $S_{17 / 2}$ and $S_{21 / 6}$ (Table 3). In most cases, significant differences in nodule number and nodule dry mass were not determined.

Poorer nodulation and lower yields were recorded at location Velika Gorica, which was characterized by acidic soil reaction, than at Maksimir, Zagreb. These results confirm the potential adverse effect of soil acidity on nodulation and symbiotic efficiency of some strains, as described in other papers (36).

In the first year of investigation (2008), the highest total nitrogen content was obtained in the above-ground plant parts at both sites by inoculation with indigenous strains $S_{21 / 6}$ and $S_{17 / 2}$. In 2009, significantly lower nitrogen content was recorded in uninoculated treatments, while statistically significant differences between strains were not determined. Inoculation with indigenous rhizobial strains $S_{17 / 2}$ and $S_{21 / 6}$ also resulted in significantly higher protein contents in bean seed than with other indigenous strains and the reference strain. In most cases, no significant differences in seed yields were determined in dependence on the strain used. In the second year of investigation, significantly lower yields were obtained in uninoculated treatments at location Maksimir, Zagreb, while significant differences between strains were not determined. At location Velika Gorica, in the first year of investigation significantly higher seed yields were achieved with the application of isolate $S_{8 / 1}$, while in the second year no statistically significant effect of inoculation on seed yields was determined. However, the lowest yields were always recorded in the control, uninoculated trial treatments. According to the assessment of the symbiotic efficiency of indigenous strains, the best results were achieved with the application of strain $S_{17 / 2}$ and the genetically specific strain $S_{21 / 6}$.

Besides, the overall results of the field trials indicate a considerable influence of environmental conditions, particularly soil properties, on inoculation response. The weaker effect of inoculation at the location Velika Gorica was largely influenced by soil acidity. This also confirms the inhibitory effect of high soil acidity on the efficiency of the symbiotic nitrogen fixation process. Although some acid-tolerant rhizobia were identified in several studies $(37,38)$, in most cases soil acidity greatly influences nodulation and persistence of rhizobia (39). Nodulation was in most cases significantly higher when indigenous rhizobial strains were applied than when they were inoculated with the reference strain. This was particularly expressed under the unfavourable conditions of high soil acidity at the location Velika Gorica, where inoculation with indigenous strains resulted in better nodulation than the inoculation with the reference strain. This result confirms that 
Table 3. Mean values of nodule number, nodule dry mass and nitrogen content in aerial parts of common bean, seed yield and seed protein content and significance of their differences at the locations Maksimir, Zagreb and Velika Gorica

\begin{tabular}{|c|c|c|c|c|c|c|c|c|c|c|}
\hline & \multicolumn{10}{|c|}{ Maksimir, Zagreb } \\
\hline & \multicolumn{5}{|c|}{2008} & \multicolumn{5}{|c|}{2009} \\
\hline & $\begin{array}{l}\frac{\partial}{J} \\
\frac{z}{0} \\
\frac{\partial}{z} \\
z\end{array}$ & 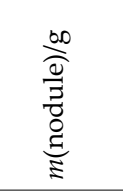 & 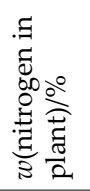 & 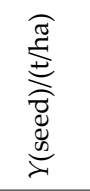 & 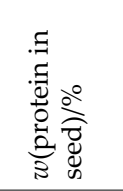 & 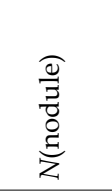 & $\begin{array}{l}\frac{0}{\overparen{O}} \\
\frac{0}{J} \\
\frac{0}{\Xi} \\
\stackrel{\Xi}{\Xi}\end{array}$ & 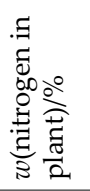 & 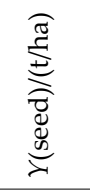 & 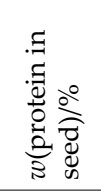 \\
\hline \multicolumn{11}{|c|}{ Strain } \\
\hline $\mathrm{S}_{\mathrm{B} 0}$ & $14.38^{\mathrm{b}}$ & $0.0270^{\mathrm{d}}$ & $1.83^{\mathrm{c}}$ & 0.79 & $23.403^{\mathrm{d}}$ & $3.75^{c}$ & $0.0066^{c}$ & $2.06^{\mathrm{b}}$ & $1.10^{\mathrm{b}}$ & $20.111^{\mathrm{b}}$ \\
\hline $\mathrm{S}_{3622}$ & $32.38^{\mathrm{a}}$ & $0.0590^{\mathrm{a}}$ & $2.30^{\mathrm{b}}$ & 0.95 & $24.264^{\mathrm{bc}}$ & $10.38^{\mathrm{bc}}$ & $0.0145^{\mathrm{c}}$ & $2.66^{\mathrm{a}}$ & $1.44^{\mathrm{a}}$ & $21.462^{\mathrm{a}}$ \\
\hline$S_{7 / 3}$ & $32.63^{\mathrm{a}}$ & $0.0470^{\mathrm{bc}}$ & $2.30^{\mathrm{b}}$ & 0.91 & $24.230^{c}$ & $16.63^{\mathrm{ab}}$ & $0.0257^{\mathrm{b}}$ & $2.87^{\mathrm{a}}$ & $1.41^{\mathrm{a}}$ & $21.424^{\mathrm{a}}$ \\
\hline $\mathrm{S}_{8 / 1}$ & $35.38^{\mathrm{a}}$ & $0.0500^{\mathrm{abc}}$ & $2.31^{\mathrm{ab}}$ & 0.89 & $24.300^{\mathrm{abc}}$ & $13.75^{\mathrm{ab}}$ & $0.0364^{\mathrm{a}}$ & $2.66^{\mathrm{a}}$ & $1.50^{\mathrm{a}}$ & $21.414^{\mathrm{a}}$ \\
\hline$S_{12 / 5}$ & $28.75^{\mathrm{a}}$ & $0.0460^{c}$ & $2.33^{\mathrm{ab}}$ & 0.99 & $24.004^{c}$ & $18.00^{\mathrm{ab}}$ & $0.0307^{\mathrm{ab}}$ & $2.63^{\mathrm{a}}$ & $1.27^{\mathrm{ab}}$ & $21.830^{\mathrm{a}}$ \\
\hline$S_{17 / 2}$ & $33.25^{\mathrm{a}}$ & $0.0510^{\mathrm{abc}}$ & $2.35^{\mathrm{ab}}$ & 1.02 & $24.828^{\mathrm{a}}$ & $21.75^{\mathrm{a}}$ & $0.0386^{\mathrm{a}}$ & $2.59^{\mathrm{a}}$ & $1.39^{\mathrm{a}}$ & $21.924^{\mathrm{a}}$ \\
\hline$S_{21 / 6}$ & $38.88^{\mathrm{a}}$ & $0.0570^{\mathrm{ab}}$ & $2.37^{\mathrm{a}}$ & 0.90 & $24.804^{\mathrm{ab}}$ & $17.75^{\mathrm{ab}}$ & $0.0359^{a}$ & $2.69^{a}$ & $1.42^{\mathrm{a}}$ & $21.525^{\mathrm{a}}$ \\
\hline \multicolumn{11}{|c|}{ Cultivar } \\
\hline $\mathrm{T}$ & 29.25 & 0.0450 & 2.25 & $1.11^{\mathrm{a}}$ & 24.220 & 15.07 & 0.0280 & 2.56 & $1.44^{\mathrm{a}}$ & 21.392 \\
\hline \multirow[t]{4}{*}{ SZ } & 32.36 & 0.0510 & 2.26 & $0.73^{\mathrm{b}}$ & 24.304 & 14.07 & 0.0280 & 2.62 & $1.28^{\mathrm{b}}$ & 21.377 \\
\hline & \multicolumn{10}{|c|}{ Velika Gorica } \\
\hline & \multicolumn{5}{|c|}{2008} & \multicolumn{5}{|c|}{2009} \\
\hline & $\begin{array}{l}\frac{\partial}{J} \\
\frac{J}{0} \\
\tilde{E} \\
z\end{array}$ & 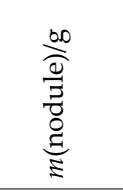 & 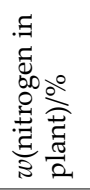 & 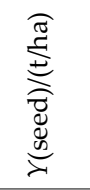 & 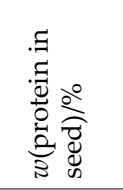 & $\begin{array}{l}\frac{\widehat{\theta}}{J} \\
\frac{0}{0} \\
\frac{E}{z}\end{array}$ & 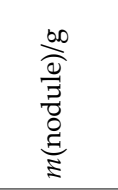 & 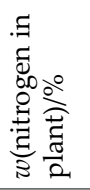 & 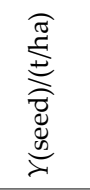 & 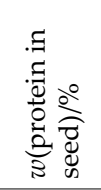 \\
\hline \multicolumn{11}{|c|}{ Strain } \\
\hline $\mathrm{S}_{\mathrm{B} 0}$ & $1.80^{\mathrm{c}}$ & 0.0003 & $1.90^{c}$ & $0.82^{\mathrm{c}}$ & $23.205^{\mathrm{d}}$ & $0.55^{\mathrm{c}}$ & $0.0010^{\mathrm{b}}$ & $3.07^{\mathrm{b}}$ & 0.80 & 25.495 \\
\hline $\mathrm{S}_{3622}$ & $3.38^{\mathrm{bc}}$ & 0.0020 & $2.35^{\mathrm{b}}$ & $1.04^{\mathrm{bc}}$ & $24.476^{c}$ & $5.88^{\mathrm{bc}}$ & $0.0060^{\mathrm{ab}}$ & $3.52^{\mathrm{a}}$ & 0.87 & 25.304 \\
\hline$S_{7 / 3}$ & $20.13^{a}$ & 0.0070 & $2.35^{\mathrm{b}}$ & $1.04^{\mathrm{bc}}$ & $24.563^{\mathrm{bc}}$ & $3.25^{\mathrm{abc}}$ & $0.0090^{\mathrm{ab}}$ & $3.62^{\mathrm{a}}$ & 0.89 & 26.105 \\
\hline$S_{8 / 1}$ & $15.38^{\mathrm{a}}$ & 0.0050 & $2.37^{\mathrm{b}}$ & $1.39^{\mathrm{a}}$ & $24.603^{\mathrm{bc}}$ & $14.13^{\mathrm{ab}}$ & $0.0140^{\mathrm{a}}$ & $3.59^{\mathrm{a}}$ & 0.92 & 25.674 \\
\hline$S_{12 / 5}$ & $12.88^{\mathrm{ab}}$ & 0.0800 & $2.36^{\mathrm{b}}$ & $1.13^{\mathrm{ab}}$ & $24.281^{c}$ & $11.50^{\mathrm{ab}}$ & $0.0120^{\mathrm{a}}$ & $3.47^{\mathrm{a}}$ & 0.82 & 25.392 \\
\hline$S_{17 / 2}$ & $17.25^{\mathrm{a}}$ & 0.0090 & $2.44^{\mathrm{a}}$ & $1.06^{\mathrm{bc}}$ & $25.324^{\mathrm{a}}$ & $15.25^{\mathrm{a}}$ & $0.0140^{\mathrm{a}}$ & $3.50^{\mathrm{a}}$ & 0.92 & 25.507 \\
\hline$S_{21 / 6}$ & $16.64^{\mathrm{a}}$ & 0.0060 & $2.40^{\mathrm{ab}}$ & $0.91^{\mathrm{bc}}$ & $25.096^{\mathrm{ab}}$ & $14.50^{\mathrm{ab}}$ & $0.0150^{\mathrm{a}}$ & $3.52^{\mathrm{a}}$ & 0.95 & 25.836 \\
\hline \multicolumn{11}{|c|}{ Cultivar } \\
\hline $\mathrm{T}$ & 11.41 & 0.0060 & 2.31 & $1.18^{\mathrm{a}}$ & 24.519 & 9.70 & 0.0090 & 3.54 & $0.96^{\mathrm{a}}$ & 25.901 \\
\hline SZ & 13.57 & 0.0040 & 2.31 & $0.92^{\mathrm{b}}$ & 24.495 & 10.31 & 0.0110 & 3.40 & $0.80^{\mathrm{b}}$ & 25.331 \\
\hline
\end{tabular}

Factor level mean values with different letters in superscript are significantly different with an error of $\mathrm{p}<0.05$. $N=$ nodule number per plant; T=Trešnjevac, SZ=Slavonski zeleni

indigenous rhizobial strains are better adaptable to adverse environmental conditions. Beneficial effect of inoculation with indigenous common bean rhizobia was also determined in different studies performed in Brazil $(40,41)$, Tunisia (42) and Spain (43).

Since symbiotic efficiency of rhizobia greatly depends on the host plant (44), these investigations included two common bean cultivars, Trešnjevac and Slavonski zeleni. Compatibility of both cultivars with all the tested strains was determined. Significant differences between common bean cultivars in all parameters were not found, with the exception of seed yield. During both years of investigation, significantly higher seed yield of Trešnjevac cultivar was recorded at both locations.
To our knowledge, these are the first studies of indigenous common bean rhizobial populations in Croatia, and the beginning of characterization and selection of indigenous strains. Further studies are needed in order to obtain more data on the composition of rhizobial populations in different regions and to perform more detailed characterization of indigenous common bean rhizobia.

\section{Conclusions}

Common bean rhizobia were isolated only from five out of 23 investigated soil samples, showing low abundance of indigenous rhizobia. Presence of only one species (Rhizobium leguminosarum) was confirmed, although 
considerable level of genetic diversity was found at intraspecies level. The positive impact of inoculation was determined on all studied parameters in comparison with uninoculated controls. The overall results of field trials revealed that two indigenous isolates $\left(S_{21 / 6}\right.$ and $\left.S_{17 / 2}\right)$ were the most efficient ones and therefore they can be used in further selection programs. Results of field trials clearly confirm the importance of rhizobial strain selection since significant differences in all tested parameters were determined depending on the strain used for inoculation. The obtained data can contribute to a better understanding of rhizobial ecology and efficient selection of rhizobial strains for a particular agroecological area.

\section{Acknowledgement}

This work was supported by a project from Ministry of Science, Education and Sports of the Republic of Croatia (178-1780692-0558) and a project from Zagreb County.

\section{References}

1. Lazali M, Bargaz A, Carlsson G, Ounane SM, Drevon JJ. Discrimination against ${ }^{15} \mathrm{~N}$ among recombinant inbred lines of Phaseolus vulgaris L. contrasting in phosphorus use efficiency for nitrogen fixation. J Plant Physiol. 2014;171:199-204. http://dx.doi.org/10.1016/j.jplph.2013.07.009

2. Ribeiro RA, Ormeño-Orrillo E, Fuzinatto Dall'Agnol R, Graham PH, Martinez-Romero E, Hungria M. Novel Rhizobium lineages isolated from root nodules of common bean (Phaseolus vulgaris L.) in Andean and Mesoamerican areas. Res Microbiol. 2013;164:740-8. http://dx.doi.org/10.1016/j.resmic.2013.05.002

3. Fuzinatto Dall'Agnol R, Ribeiro RA, Ormeño-Orrillo E, Rogel MA, Marçon Delamuta, Andrade DS, et al. Rhizobium freirei sp. nov., a symbiont of Phaseolus vulgaris that is very effective at fixing nitrogen. Int J Syst Evol Microbiol. 2013; 63:4167-73.

http://dx.doi.org/10.1099/ijs.0.052928-0

4. Mnasri B, Liu TY, Saidi S, Chen WF, Chen WX, Zhang XX, Mhamdi R. Rhizobium azibiense sp. nov., a nitrogen fixing bacterium isolated from root-nodules of Phaseolus vulgaris. Int J Syst Evol Microbiol. 2014;64:1501-6.

http://dx.doi.org/10.1099/ijs.0.058651-0

5. Nleya T, Walley F, Vandenberg A. Response of four common bean cultivars to granular inoculant in short-season dryland production system. Can J Plant Sci. 2001;81:385-90. http://dx.doi.org/10.4141/P00-098

6. Rodriguez-Navarro DN, Buendia AM, Camacho M, Lucas MM, Santamaria C. Characterization of Rhizobium spp. bean isolates from South-West Spain. Soil Biol Biochem. 2000;32: 1601-13. http://dx.doi.org/10.1016/S0038-0717(00)00074-2

7. De Ron AM, Papa R, Biocchi E, González AM, Debouck DG, Brick MA, et al. Common bean. In: de Ron AM, editor. Handbook of plant breeding, vol. 19, Grain legumes. New York, NY, USA: Springer-Verlag; 2015. pp. 1-36. http://dx.doi.org/10.1007/978-1-4939-2797-5

8. Lešić R. Family Fabaceae. In: Lešić R et al, editors. Vegetable production. Čakovec, Croatia: Zrinski d.d.; 2004. pp. 548-60 (in Croatian).

9. Faghire M, Mandri B, Oufdou K, Bargaz A, Ghoulam C, Ramírez-Bahena $\mathrm{MH}$, Velázquez E, Peix A. Identification at the species and symbiovar levels of strains nodulating Phaseolus vulgaris in saline soils of the Marrakech region
(Morocco) and analysis of the otsA gene putatively involved in osmotolerance. Syst Appl Microbiol. 2012;35:156-64. http://dx.doi.org/10.1016/j.syapm.2012.02.003

10. Hungria M, Andrade DS, Chueire LM, Probanza A, Guttierez-Mañero FJ, Megías M. Isolation and characterization of new efficient and competitive bean (Phaseolus vulgaris L.) rhizobia from Brazil. Soil Biol Biochem. 2000;32:1515-28. http://dx.doi.org/10.1016/S0038-0717(00)00063-8

11. Wang L, Ying C, Wang ET, Qiao YJ, Jiao S, Liu ZS, et al. Biodiversity and biogeography of rhizobia associated with common bean (Phaseolus vulgaris L.) in Shaanxi Province. Syst Appl Microbiol. 2016;39:211-9.

http://dx.doi.org/10.1016/j.syapm.2016.02.001

12. Redžepović S, Sikora S, Čolo J, Blažinkov M, Pecina M. Influence of plant growth regulator and rhizobial inoculation on nodulation and soybean nitrogen content. Cereal Res Commun. 2007;35:993-6.

http://dx.doi.org/10.1556/CRC.35.2007.2.207

13. Sikora S, Blažinkov M, Babić K, Sudarić A, Redžepović S. Symbiotic nitrogen fixation and sustainable soybean production. Cereal Res Commun. 2008;36:1483-6.

14. Blažinkov M, Sikora S, Uher D, Maćešić D, Redžepović S. Genotypic characterisation of indigenous Rhizobium leguminosarum bv. viciae field population in Croatia. Agric Conspec Sci. 2007;72:153-8.

15. Blažinkov $M$, Uher $\mathrm{D}$, Redžepović $\mathrm{S}$, Maćešić $\mathrm{D}$, Čolo J, Štafa $Z$, Sikora S. Effectiveness of inoculation in alfalfa breeding in ecological conditions of the Bjelovar and Bilogora county. Mljekarstvo. 2012;62:200-6.

16. Nelson DW, Sommers LE. Total carbon, organic carbon, organic matter. In: Page AL, Miller RH, Keeney DR, editors. Methods of soil analysis. Madison, WI, USA: Soil Science Society of America, Inc.; 1982. pp. 574-7.

17. HRN ISO 11261:2004. Soil quality - Determination of total nitrogen - Modified Kjeldahl method (ISO 11261:1995). Geneva, Switzerland: International Organization for Standardization (ISO); 2004 (in Croatian).

18. Egner $\mathrm{H}$, Riehm H, Domingo WR. Investigation of soil chemical properties as a basis for assessing soil nutrient status. II: Chemical extraction methods for phosphorus and potassium determination. Kunglia Landboukshogskolans Annaler; 1960. pp. 199-215 (in German).

19. Vincent JM. A manual for the practical study of the root nodule bacteria. IBP handbook no. 15. Oxford, UK: Blackwell Scientific Publications; 1970.

20. Sikora S, Redžepović S. Genotypic characterisation of indigenous soybean rhizobia by PCR-RFLP of $16 \mathrm{~S}$ rDNA, rep-PCR and RAPD analysis. Food Technol Biotecnol. 2003;41: 61-7.

21. Somasegaran P, Hoben HJ. Handbook for rhizobia. New York, NY, USA: Springer-Verlag; 1994. http://dx.doi.org/10.1007/978-1-4613-8375-8

22. Andrade DS, Murphy PJ, Giller KE. Effects of liming and legume/cereal cropping on population of indigenous rhizobia in an acid Brazilian oxisol. Soil Biol Biochem. 2002;34:477585. http://dx.doi.org/10.1016/S0038-0717(01)00206-1

23. Ludwig W, Klenk HP. Overview: a phylogenetic backbone and taxonomic framework for prokaryotic systematic. In: Brenner DJ, Krieg NR, Staley JT, editors. Bergey's manual of systematic bacteriology. New York, NY, USA: Springer; 2005. pp. 49-65.

24. Junier P, Alfaro M, Guevara R, Witzel KP, Carú M. Genetic diversity of Rhizobium present in nodules of Phaseolus vulgaris L. cultivated in two soils of the central region in Chile. Appl Soil Ecol. 2014;80:60-6.

http://dx.doi.org/10.1016/j.apsoil.2014.03.014 
25. Aserse AA, Räsänen LA, Assefa F, Hailemariam A, Lindström K. Phylogeny and genetic diversity of native rhizobia nodulating common bean (Phaseolus vulgaris L.) in Ethiopia. Syst Appl Microbiol. 2012;35:120-31. http://dx.doi.org/10.1016/j.syapm.2011.11.005

26. Cao Y, Wang ET, Zhao L, Chen WM, Wei GH. Diversity and distribution of rhizobia nodulated with Phaseolus vulgaris in two ecoregions of China. Soil Biol Biochem. 2014;78:128-37. http://dx.doi.org/10.1016/j.soilbio.2014.07.026

27. Adhikari D, Itoh K, Suyama K. Genetic diversity of common bean (Phaseolus vulgaris L.) nodulating rhizobia in Nepal. Plant Soil. 2013;368:341-53. http://dx.doi.org/10.1007/s11104-012-1518-7

28. Rashid MH, Schäfer H, Gonzalez J, Wink M. Genetic diversity of rhizobia nodulating lentil (Lens culinaris) in Bangladesh. Syst Appl Microbiol. 2012;35:98-109. http://dx.doi.org/10.1016/j.syapm.2011.11.008

29. Iglesias O, Rivas R, García-Fraile P, Abril A, Mateos PF, Martínez-Molina E, Velázquez E. Genetic characterization of fast-growing rhizobia able to nodulate Prosopis alba in North Spain. FEMS Microbiol Lett. 2007;277:210-6. http://dx.doi.org/10.1111/j.1574-6968.2007.00968.x

30. Moschetti G, Peluso A, Protopapa A, Anastasio M, Pepe O, Defez R. Use of nodulation pattern, stress tolerance, nodC gene amplification, RAPD-PCR and RFLP-16S rDNA to discriminate genotypes of Rhizobium leguminosarum biovar. viciae. Syst Appl Microbiol. 2005;28:619-31. http://dx.doi.org/10.1016/j.syapm.2005.03.009

31. Valverde A, Igual JM, Peix A, Cervantes E, Velázquez E. Rhizobium lusitanum sp. nov. A bacterium that nodulates Phaseolus vulgaris. Int J Syst Evol Microbiol. 2006;56:2631-7. http://dx.doi.org/10.1099/ijs.0.64402-0

32. Lu YL, Chen WF, Wang ET, Guan SH, Yan XR, Chen WX. Genetic diversity and biogeography of rhizobia associated with Caragana species in three ecological regions of China. Syst Appl Microbiol. 2009;32:351-61. http://dx.doi.org/10.1016/j.syapm.2008.10.004

33. Fierer N, Jackson RB. The diversity and biogeography of soil bacterial communities. Proc Natl Acad Sci USA. 2006;103: 626-31. http://dx.doi.org/10.1073/pnas.0507535103

34. Donnarumma F, Bazzicalupo M, Blažinkov M, Mengoni A, Sikora S, Huić Babić K. Biogeography of Sinorhizobium meliloti nodulating alfalfa in different Croatian regions. Res Microbiol. 2014;165:508-16. http://dx.doi.org/10.1016/j.resmic.2014.06.001
35. Asadi Rahmani H, Räsänen LA, Afshari M, Lindström K. Genetic diversity and symbiotic effectiveness of rhizobia isolated from root nodules of Phaseolus vulgaris L. grown in soils of Iran. Appl Soil Ecol. 2011;48:287-93. http://dx.doi.org/10.1016/j.apsoil.2011.04.010

36. Coventry DR, Evans J. Symbiotic nitrogen fixation and soil acidity. In: Robson AD, editor. Soil acidity and plant growth. Sydney, Australia: Academic Press; 1989. pp. 103-37. http://dx.doi.org/10.1016/B978-0-12-590655-5.50008-6

37. Graham PH, Viteri SE, Mackie F, Vargas AT, Palacios A. Variation in acid soil tolerance among strains of Rhizobium phaseoli. Field Crops Res. 1982;5:121-8. http://dx.doi.org/10.1016/0378-4290(82)90012-0

38. Román-Ponce B, Zhang YJ, Vásquez-Murrieta MS, Sui XH, Chen WF, Alberto Padilla JC, et al. Rhizobium acidisoli sp. nov., isolated from root nodules of Phaseolus vulgaris in acid soils in Mexico. Int J Syst Evol Microbiol. 2016;66:398406.

http://dx.doi.org/10.1099/ijsem.0.000732

39. Zahran HH. Rhizobium-legume symbiosis and nitrogen fixation under severe conditions and in an arid climate. Microbiol Mol Biol Rev. 1999;63:968-89.

40. Hungria M, Campo RJ, Carvalho Mendes I. Benefits of inoculation of the common bean (Phaseolus vulgaris) crop with efficient and competitive Rhizobium tropici strains. Biol Fertil Soils. 2003;39:88-93. http://dx.doi.org/10.1007/s00374-003-0682-6

41. Mostasso L, Mostasso FL, Dias BG, Vargas MAT, Hungria M. Selection of bean (Phaseolus vulgaris L.) rhizobial strains for the Brazilian Cerrados. Field Crops Res. 2002;73:121-32. http://dx.doi.org/10.1016/S0378-4290(01)00186-1

42. Mrabet M, Mhamdi R, Tajini F, Tiwari R, Trabelsi M, Aouani ME. Competitiveness and symbiotic effectiveness of R. gallicum strain isolated from root nodule of Phaseolus vulgaris. Eur J Agron. 2005;22:209-16. http://dx.doi.org/10.1016/j.eja.2004.02.006

43. Mulas D, García-Fraile P, Carro L, Ramírez-Bahena MH, Casquero P, Velázquez E, González-Andrés F. Distribution and efficiency of Rhizobium leguminosarum strains nodulating Phaseolus vulgaris in Northern Spanish soils: selection of native strains that replace conventional $\mathrm{N}$ fertilization. Soil Biol Biochem. 2011;43:2283-93. http://dx.doi.org/10.1016/j.soilbio.2011.07.018

44. Giongo A, Passaglia LMP, Freire JRJ, de Sá ELS. Genetic diversity and symbiotic efficiency of population of rhizobia of Phaseolus vulgaris L. in Brazil. Biol Fertil Soils. 2007;43:593-8. http://dx.doi.org/10.1007/s00374-006-0128-z 